\begin{tabular}{c} 
Volume and Issues Obtainable at Center for Sustainability Research and Consultancy \\
Journal of Accounting and Finance in Emerging Economies \\
ISSN: 2519-0318 ISSN (E) 2518-8488 \\
Volume 7: Issue 1 March 2021 \\
CSRC \\
Journal homepage: $\underline{\text { ww.publishing.globalcsrc.org/jafee }}$ \\
\hline
\end{tabular}

\title{
Accelerating Company Performance through Dividend Payout Policy: A Trend Analysis of Automobile Sector Listed in Pakistan Stock Exchange
}

\begin{tabular}{|c|c|}
\hline \multicolumn{2}{|c|}{$\begin{array}{l}{ }^{1} \text { Nisar Ahmad, }{ }^{2} \text { Mohsin Nazir, }{ }^{3} \text { Naseer Abbas } \\
\text { e for Women University, Lahore, Pakistan, nisarbazmi71@ @mail.com } \\
\text { ge for Women University, Lahore, Pakistan, } \underline{\text { mohsinsage@ @mail.com }} \\
\text { al Open University, Islamabad, Pakistan, naseerabbas34@gmail.com }\end{array}$} \\
\hline ARTICLE DETAILS & ABSTRACT \\
\hline History & The study explains the relationship of dividend payout policy on the \\
\hline Revised format: February & business performance of companies that exist in automobile sector of \\
\hline 2021 & Pakistan. 100 companies are selected from automobile sector. \\
\hline Available Online: March & Relationship of dividend payout policy and business performance \\
\hline 2021 & was controlled with four variables based on relevant theories. These \\
\hline Keywords & variables include size of company, growth of company leverage debt \\
\hline Dividend payout Policy, & to equity ratio and corporate governance index. Panel data is \\
\hline Tobin's Q, Size, Growth, & collected from 2012-2017 six years and then analyzed with unit root, \\
\hline Leverage, Corporate & descriptive statistics, correlation analysis, OLS regression, Lagrange \\
\hline Governance Index. & multiplier, Huasman test, fixed effect and Random effect models. \\
\hline $\begin{array}{l}\text { JEL Classification: } \\
M 40, M 49\end{array}$ & Following key findings for each research objective were obtained by \\
\hline & $\begin{array}{l}\text { applying the adopted research method on the data througn the } \\
\text { companies showed positive relationship between their dividend } \\
\text { payout policy and profitability and it was concluded that both } \\
\text { dependent and independent variables are positively related in this } \\
\text { sector and size, growth and leverage are the controlling predictors of } \\
\text { the relationship. }\end{array}$ \\
\hline ACCESS & $\begin{array}{r}\text { (C) } 2020 \text { The authors, under a Creative Commons Attribution- } \\
\text { NonCommercial } 4.0\end{array}$ \\
\hline
\end{tabular}

Corresponding author's email address: nisarbazmi71@gmail.com

Recommended citation: Ahmad, N., Nazir, M. \& Abbas, N. (2021). Accelerating Company Performance through Dividend Payout Policy: A Trend Analysis of Automobile Sector Listed in Pakistan Stock Exchange. Journal of Accounting and Finance in Emerging Economies, 7(1), 117-141

\section{Introduction}

Profitability of a business is the major economic drive for companies and they can attribute their profit towards two main heads. Either they can go for retained earning i-e can hold their earning in the firm to use it in future investment for growth purposes or they can distribute this earning to shareholders (Yegon et al., 2014). The distribution of profit is mainly done as dividends, this is why, it is crucial for firms to design a dividend payout policy to determine that whether to pay dividends and if yes then what should be the percentage of payouts or if it is more suitable for the financial benefits of business to invest the profit in future growth (Khan, et al. 2016). Privatization, globalization and liberalization in Pakistan economy along with the growing integration of information technology in business have caused intense competitive environment in every industry and business. On the other hand, this situation has also confused, dazed and bewildered Pakistani corporate stakeholders because they know that in order to thrive in this competitive environment, it is crucial for them to increase the value of their firms (Farrukh 
et al., 2017). In order to do so, finance managers of companies have to deal with the decisions related to the basic budgetary of business so they can meet the goal of increasing their firms' value by expanding the engagement of shareholders along with increasing the performance and profitability of their firms (Adediran and Alade, 2013). It is evident that financial performance is very important and financial behavior of a firm revolves around number of key decisions including management of working capital, investments and dividend policy, among which dividend distribution holds a key position (Younis and Javid, 2014). Jaffe, Westerfield \& Ross (2002) stated that the importance of dividend decision greatly lies in the fact that it helps the finance managers to forecast the fund amount that they can distribute in shareholders as dividend payouts and the remaining amount to be reserved for making investments in future time period. This policy also helps the stakeholders to obtain the information associated with the performance of a company because the major interest of an investor in investing his or her savings in a business is to gain profit on them. The common source of income is seen in a dividend by the investors who are averse to in a setting where businesses operate in very competitive era and maintain its performance and quality to maintain their statuesque. All these matters make the making of dividend payout policy a very important decision as it helps in maintaining the attractiveness of an organization (Bhattacharyya, 2007). The dividend plans in corporate world varies according host country on the firm being industrialized or unindustrialized and other financial situations such as earning patterns, size and growth of the firm. It was found out that dividend payout policy varies from company to company based or internal situation and market pressure (Ramcharan, 2001).

The relevancy or irrelevancy of dividend payout policy for financial decisions in developed and developing countries has been studied in previous literature (Rahman, 2018; Hasan, 2015; Lai et al., 2016; Chauhan et al., 2019). Currently the focus has shifted to the determinants and control predictors to decide dividend policies and their significance to the business performance. It is evident that dividend policies in Pakistani stock market has a different behavior with performance of companies from that in other stock market including developed countries and other developing countries, even the behavior is different at industrial level (Khan et al, 2016). Therefore current study aims to further extend the debate related to dividend payout policy in Pakistan's industries with regards to the fact that which controlling predictors for the dividend payout ratio affects the dividend payout policy and how these predictors influence the financial performance at industrial level in terms of asset returns i-e generally abbreviated as ROA, earning per share or EPS and Tobin's Q. Automobile Sector of Pakistan are taken under study to explore and investigate the predictors related to dividend payout policy that can define the behavior of company performance mainly in these industries.

\section{Problem Statement}

All the challenges which arise for financial managers of organizations in making dividend payout policy for a company and other dynamics that are mentioned in the above section makes it crucial for all the stakeholders to study that how the aspects of a dividend payout policy can influence the performance of an organization. Although number of researches are conducted to study the ups and downs of dividend payout policy but still a lot is known in terms that on what line of thoughts, an organization makes its dividend payout policy and to know that it is crucial to explore the effects that what kind of policy influence the company performance in what way. The current study has taken under study that how the companies need to interpret the controlling role of size and growth of the company, leverage and governance practices to the relationship of business performance and dividend policy.

\section{Research Questions}

a) What is the role of company's dividend payout policy on performance in terms of returns on equity (ROE)?

b) What is the role of company's dividend payout policy on performance in terms of earnings per share (EPS)? 
c) What is the role of company's dividend payout policy on performance in terms of Tobin's $\mathrm{Q}$ ?

d) Does size of company, corporate governance practices, leverage and growth of company control relationship of decided dividend payout and performance indictor returns on equity (ROE)?

e) Does size of company, corporate governance practices, leverage and growth of company control relationship of decided dividend payout and performance indictor earnings per share (EPS)?

f) Does size of company, corporate governance practices, leverage and growth of company control relationship of decided dividend payout and performance indictor Tobin's Q?

\section{Primary Objectives}

a) To study the influence of decided dividend payout policy on performance of business in terms of returns on equity for automobile sector of Pakistan.

b) To study the influence of decided dividend payout policy on performance of business in terms of earnings per share for automobile sector.

c) To study the influence of decided dividend payout policy on performance of business in terms of Tobin's Q for automobile sector.

\subsection{Secondary Objectives}

d) To study the significance of size of company, corporate governance practices, leverage and growth of company to control over the association between decided dividend payout and business performance in terms of returns on equity for automobile sector of Pakistan.

e) To study the significance of size of company, corporate governance practices, leverage and growth of company to control over the association between decided dividend payout and business performance in terms of earnings per share for automobile sector.

f) To study the significance of size of company, corporate governance practices, leverage and growth of company to control over the association between decided dividend payout and business performance in terms of Tobin' Q for selected automobile sector of Pakistan.

\section{Literature Review}

Decision on whether to pay dividend or not and its influence on organizational performance is considered as one of the debatable topics in financial management. Regardless of the extensive research carried out, researchers have not reached any general finding or acceptance in terms off dividend payout policy and its influence on business performance. Profit is earned by every successful business, however, in general, the question is raised that in the form of dividend, how much profit should be distributed to shares holders and how much should be retained for future needs. Such decisions are influenced by a firm's dividend policy. One of the key elements of corporate policy is the firm's dividend policy. Generally, dividend payout policy is the rules and principles which firm employs to decide payments of dividends to shareholders. As the dividend payout policy is important aspect of a company, the decision regarding optimal dividend is highly crucial. Fundamentally, dividends are the benefits awarded to shareholders in return of risking their investments in the business and it is determined by several predictors in a firm. These predictors include chances and choice of investment, size of firm, limitations of funds, regulatory administrations, shareholders pressure, and cash flows. Generally, there are two schools of thoughts on dividend policy. Miller \& Modigliani (1961) and Myer (2007) in their respective studies asserted that firm's value cannot be determined by its dividend policy, implying that dividend payout policy is irrelevant. On the other hand, the proponents i.e. Lintner (1956) 
and Fama \& Babiak (1968) in their studies argued that in the developed stock markets, previous dividends influence the firms' dividend payout ratio. The irrelevance theory explains that if a firm generates profits under a fully competitive market, it does not have a positive influence on the value of the company. The value can be only increased if retained earnings are invested in projects with high yield, thus there exists no relationship between dividend payout and firm's value. Whereas, the relevance theory postulates that dividend payout are requested by investors with the anticipation that it will positively affect value of the firm. This chapter covers the literature review including the relevant theories discussing the concept of dividend payout policy and its relevancy or irrelevancy to the business performance while other related theories discussing the concept of controlling influence of size, leverage, growth and corporate governance index. Next, this chapter also covers the empirical reviews on relationship between dividend payout policy and business performance with controlling influence of size, leverage, growth and corporate governance index.

\subsection{Dividend}

In any corporation, the management decides whether to pay out earnings in forms of dividends to its shareholders or the amount must be retained to support internal operations. When the firms earn profits, they usually pay dividends to their shareholders. There are different proposed definitions of dividends. Dividends are paid after the declaration from Board of Directors (Toby, 2014). Dividends are earnings of the firms that are left after tax deduction and are distributed to shareholders (Rustagi, 2001). Dividends are the portion of the net earnings that shareholders get in form of cash or non-cash. Dividends are distributed to the equity shareholders and it is a sort of reward because they have invested in the company (Shah, 2015). Dividends are the return on the investment for shareholders because they have invested in the firm through purchasing shares (Maheshwari, 1999). According to business jargons, dividend payout policy is another name of a financial decision that explains about how the earnings/proportion of earnings of the firm will be distributed among its shareholders (Business Jargons, 2017). This is on company's discretion that if it will distribute portion of profits as dividends or it will retain the earnings to plough it back into business and raise the price of share (Motley, 2017). Dividend payment ratio is the determinant of the investor's decision to invest (Omodero \& Amah, 2017). The firms paying huge amounts of dividends are more likely to attract the investors. However, in perspective of firms, the high dividends are financial burden for the firm. To reduce this burden, the firms that pay high dividends tries to reduce the payments at a certain level so that financial position can be maintained (Tara \& Raja, 2014). The performance of the asset is dependent on the policies of the managers. This performance of asset basically determines the dividend, and every financial manager should work hard so that shareholder's wealth can be maximized, pay them a handsome dividend and gives a complete understanding of dividend payout policy to the shareholder (Omodero \& Amah, 2017). Dividend decision is crucial decision out of all financial decisions a firm make. Dividend payout policy is a key that helps the manager to decide the allocation of financial resources. Dividend payout policy also helps the firms in maximization of the wealth of its shareholders (Kuzucu, 2015). If the dividend decisions are not opted well, it can affect shareholder's wealth. Dividends have been the most debatable and core topic in the finance domain as it proposes answers to dividend-puzzle. There are a lot of financial aspects that can help in determining the dividends for shareholders. These aspects include the mergers, acquisitions, asset pricing, capital budgeting, and capital structure theories. There are various determinants of dividends and some predictors that can help the firms and researchers about the dividend-puzzle. These predictors include nature of industry, area of work, profit distribution ratio, additional capital and methods of financing, age of the corporation, trade cycles, policies of government, political stability, taxation policies, liquidity position and cash balance (Islam et al., 2017). The theoretical basis of the dividend payout policy and dividend models are agency costs, transaction costs, taxes, demands or preferences of shareholders, informational content and clientele effects. The firmspecific predictors usually influence the dividend-payout ratios and are the determinants of the dividends. Dividend payments can be affected by many predictors like size, capital structure, industry, profitability, maturity, firm's structure and ownership structure (Kuzucu, 2015). Dividends that a firm pays to its shareholders can be evaluated on the basis of the earnings. One of the earliest studies Lintner 
(1956) shows that earnings of the firm are core determinant of the dividend policy. This study proposed that expected earnings and changes in earnings are two main determinants of the firm's dividend policy. Earnings have been the most focused area in determining the dividend payout policy (Pruitt \& Gitman, 1991; Fama \& Babiak, 1968; Baker \& Powell, 1999).

\subsection{Theories of Dividend}

Miller and Modigliani's Dividend Irrelevance Theory

Gordon's Bird in the Hand Theory

Tax Preference Theory and Dividend Payout Policy

Signaling Theory and Dividend Policy

Pecking Order Theory of Dividends

Agency Theory of Dividends

Clientele Effect

Catering Theory of Dividends

\subsection{Types of Dividend}

Every company has some earnings and distributing these earnings or part of these earnings to the equity shareholders is known as dividend. Board of Directors usually decide that what amount should be paid as dividends. Dividends represent the financial soundness of the company and shareholder's value. If the distribution of earnings is good, then it's an indicator of positive future and strong performance. If the stable dividends are paid, it depicts that the company is performing well. There are different types of dividends like cash, bonus share, share repurchase, property, stock, scrip and liquidating dividends. Most common of all types is the cash dividend is paid to shareholders after decision on the date of declaration in form of cash (Borad, 2019). Property dividend is the non-monetary dividend that a company pays to its shareholders rather than paying stock or cash dividend. Usually there is a difference in fair market value and the book value of the asset. This difference is recorded as gain or loss. Property dividends are issue to alter the taxable/reported income. If a company issues a promissory note to the shareholders in case in near future, company runs out of enough funds for dividend payments, this is known as scrip dividend. The scrip dividend may or may not include interest (Corporate Finance Institute, 2018). When the shareholders get back the capital they invested in form of dividends, this is known as liquidating dividends. These are distributed on decision of board of directors. Liquidating dividends are usually an antecedent of the business shut down. In accounting, the liquidating and cash dividends are entered as same entities (Bragg, 2018). Bonus share and stock dividends are same entities. When the companies have low operating cash, they issue bonus shares. Share repurchase is the phenomenon when the company buy backs its own shares. In this way the number of outstanding shares is reduced. This is an alternate to the dividend payments (Borad, 2019).

\subsection{Effect of Dividend Payout Policy on Business Performance}

In the field of corporate financial management, dividend payout policy is one of the most controversial issues. Why companies should pay the dividends and why they do not pay dividends is still a debatable question for the financial managers and academia as well. There are numerous empirical and theoretical researches that explain the dividend policies and its effects on the organizational performance. However, no consensus is found on unresolved issue of dividend payment. Among the topic unresolved issues in the field of corporate finance, dividend policy decision as important one (Idewele \& Murad, 2019; Velnampy et al., 2014; Brealey and Myers, 2003). Therefore Black (1976) claimed that dividend puzzle is most difficult puzzle to solve. This is why it has been regarded as a "dividend puzzle" (Black, 1976).

Now the dividend payout policy has become the global issue because it has been accepted that it affects the firm performance. Investors usually face a lot of risks and uncertainties that cannot be predicted at the time of investment. However, the economic conditions prevailing in country, political stability of a country and firm's performance are the predictors that can help in reducing the risks an investor takes. Financial reports of any company depict a true picture about the company's performance. Investors can 
take investment decision on the basis of these financial reports. If the company has capability to raise profits, it can attract investors. However, dividend is announced for shareholders at Annual General Meeting (AGM) of the company. There are basically four decision areas of corporate finance; financing, management of working capital, investment and allocation of profits. If an investor or the stakeholder wishes to assess the company's performance, the dividend payout policy will provide the best information on this. This is because the investors usually invest for reasonable rate of return or source of income. Dividend is the source of income and most of the companies strive to operate efficiently and adopt a favorable dividend policy. The profit gained is allocated in either dividend payout or retained earnings. The dividend payout policy basically determines where the profits should be allocated (Velnampy et al., 2014).

\subsection{Relationship of Dividend and Business Performance}

A study conducted in Pakistan examined the automobile sector's performance. Data was collected from Pakistani public listed company for the period 2012-2016 and financial data of sample companies was used. OLS regression was applied for data analysis. Results showed that dividend per share (DPS) is positively associated with ROE but the relationship is insignificant. This was concluded that if the DPS is increased, the ROE also rises. The earning per share (EPS) and firm's size also tends to have a positive and significant association with ROE (Rahman, 2018). Ghanaian Stock Exchange was also examined using the published audited annual reports of different firms. 6 years data was collected from period 2009-2014. Analysis method was OLS regression to study the relationship of business performance and dividend payout. This study revealed that GDP growth, interest rates, ROE, age of the firm, taxes and tangibility all predictors significantly explain the dividend policy. Shareholder's wealth is taken as a proxy for firm's performance. There is a positive strong relationship of dividend payout policy and shareholder's wealth and managers should focus on dividend payout policy as well as investment activities so that shareholder's wealth can be maximized (Ofri-Sasu et al., 2017). The dividend payout policy also has a significant association with the Deposit Money Bank's performance. Analysis was done from 15 deposit money banks that were listed on Nigerian Stock Exchange and these were selected as a sample for study and panel data regression was used as analysis method. Dividend payout ratio was used as proxy for dividend payout policy and results indicated that as dividend payout ratio increases the financial performance gets better. So, the managers should focus on the healthy dividend policies by making investments in the projects that increases net present values and generate earnings. These earnings can be used to pay dividends (Idewele \& Murad, 2019). In Pakistani context, the association of dividend policy and firm performance was studied. For this, data was collected from energy and automobile sectors. Time span was from 1996-2008. ROA and EPS are proxied for business performance and analysis method used was logarithmic regression. In this study, the results are little bit contradictory to general perception about dividend payout policy having positive influence on business performance. In this study, the dividend payout ratio tends to have negative influence on the business performance, hence giving new dimensions to researchers (Hasan, 2015).

\subsection{Size of Firm and Business Performance}

Performance of the firm is related to the firm's size. Almost every firm strives to expand its size to gain competitive advantage. The theoretical support for increasing firm's size to achieve better performance can be best defined with help of economies of scale (Oyelade, 2019). The association of firm size and performance has been a controversial topic in the corporate finance. This depends on the firm type and organizational economists are still working to find the exact relationship. The economies of scale are the main factor that can explain the negative relationship of firm size and performance. As the firm size increases, its resources pool is also expanded and hence performance can be increased (Valeiras, 2016). If the firm size increases, the asset return increases (Chaddad \& Mondelli, 2013). It may also increase the return on equity or capital employed (Adenauer \& Heckelei, 2011). The other theoretical grounds on which the firm size can have direct association with the performance are that profit margins and returns on scale increases (Garcia-Fuentes et al., 2013). The market opportunities are also higher for the large firms that can cause the economies of scale Not only economies of scale, but the large firms have higher 
customer base, more negotiating powers with suppliers and customers and they can also access the international market easily. Large firms can save taxes and their market value and position is also greater than the small firms (Valeiras, 2016). There are many reasons in literature that explains the firm size as key indicator for judging the performance of the firm. If balance sheet is taken as proxy for the size of firm, increase in balance sheet results in better earnings. Small firms operating in a large number will act as a driving force for regulatory bodies. Securities and Exchange Commission will be active in implementation of policies like dividend payout policy, structure of capital and the corporate governance and thus improve performance. The diversification in size of firms will help in variation in performance of firms (Shah et al., 2016).

\subsection{Growth of Firm and Dividend Payout Policy}

Dividends are paid to shareholders because shareholders seek some benefit out of their investments. If the business is growing, then investors may anticipate that firm will pay dividends to its shareholders. Growth in business makes sure that the dividend payout policy will be smooth overtime (Lintner, 1956). The payments of dividends are determined by several predictors including financial position, company policy and growth of the company. By no means, dividend payments are mandatory for any company however, if the company wants, they can pay dividends to its shareholders. Sometimes the companies do not pay dividends and invest the earnings in low-cost capital projects. Managers decide to invest these earnings into projects because of their personal interests due to which agency problem is raised. Annual sales growth of the company is often an evaluation parameter for managers and that is why managers do not want to pay dividends (Bushra \& Mirza, 2015). However, literature says that more profitable the firm is, it pays huge dividends. If the firms have more opportunities for growth, its dividend payouts are less (Ahmad \& Javid, 2009). Generally, if the firm is in the stage in which it is transitioning from growth to maturity, it pays more dividends. Dividend payments are a unique feature of the business cycle. The firms that have achieved the maturity stage have fewer positive NPV (Net Present Value) projects but the cash reserves are higher. So, financial managers of mature firms can favorably distribute dividends. Mature firms have more sticky dividends and this is why it is a positive signal for investors because variations in dividend payout are considered negative signaling for investors (Moyen, 2004). The sales growth of the firm also affects the dividend policies of the firm. In some scenarios, despite achieving the higher sales growth, firms still manage to pay dividends to its shareholders. Firms usually want sales growth so that their market position can be sustained and retained. If the sales growth is higher, it implies that profitability is increasing overtime so the financial managers have more cash to rewards their shareholders. To retain free cash flows (FCF), firms usually opt to increase their sales growth (Afza \& Mirza, 2010). The firms that have higher opportunities for the growth and expansion, pay higher dividends form their free cash flows so that their reputation can be maintained (Bushra \& Mirza, 2015). The companies that have higher sales growth, they also have the need for extra funds, so that investments can be made. As, investments are cheapest financing source. Mature firms are already at the optimum level so they do not usually invest in high-growth projects. So, they pay their shareholders a huge amount of profits as dividends (Afza \& Mirza, 2011). Mature companies usually have expanded to their maximum and their growth is slower so capital expenditure is also less. Growth opportunities are usually proxied by the market-to-book (M/B) Ratio. This is most popular measure to test the growth opportunities of a firm. Growth firm having higher M/B ratio pays lower dividends. This is because if there are investment opportunities for the firms that are in growth stage, they will prefer to invest and need retained earnings for this investment. So, in this way the dividend payout is less. Growth firms also depend on the internal financing for the investments so that costs of external financing can be avoided. So, these firms pay less dividends (Bushra \& Mirza, 2015). The firms pay smooth dividends when they are growing rapidly because these firms usually want to send positive signals to the shareholder's regarding the value of firm (Epaphra \& Nyantori, 2018).

\subsection{Growth of Firm and Business Performance}

There are some theories that propose and explains the association between the growth of firms and their performance. These include managerial theory, neo classical theory, Penrose model and the theory of 
optimum firm size (Sangosanya, 2011).

\subsection{Leverage of Firm and Dividend Payout Policy}

The decision about source of financing a firm needs and dividend payout policy are the most important decisions, a firm ever makes. For financing, the firm always have a choice between internal financing and external financing. External financing includes debt and equity financing while the internal financing includes finances from depreciation and retained earnings. Therefore, a firm has to choose or evaluate two of its choices. First it must choose between the dividend payments and retained earnings. This implies that how much of the profits or earnings be kept within firm and ploughed back and how much amount must be paid as dividends. Second choice is about the capital structure/leverage. Either the firm will go for debt or equity financing (Sang et al., 2015). Dividend payout policy is the determinant of the financing choice of the firm. This is basically decided by the financial managers that whether the firm will release the corporate earnings from the control of enterprise or not. This is because dividend payout policy can have influence on the corporate liquidity, liquid fund's flow, satisfaction of the investor and stock prices (Weston \& Brigham, 1981). The major decision that a financial manager can face is the distribution of dividends (Franklin \& Roni, 1995). Not only the capital structure but dividend payout policy is crucial to understand theories of asset pricing, acquisitions, mergers and capital budgeting. Capital structure can be defined as the ratio of the funding arrangement of the firm in terms of debt or equity financing. Capital structure may comprise of debt, equity and hybrid securities that the firm issues (Brealey \& Myers, 2005). If the financial leverage increases, the returns to some shareholders can get better but at the same time, risk also increases because of the agency costs and financial distress (Jensen \& Mecking, 1976).

\subsection{Leverage of Firm and Business Performance}

When the companies decide to structure their finance, they face difficulty because its an important decision that can affect their performance. The capital structure is very important for survival and value of the firm. It is upon manager's discretion to decide about the capital structure. Managers decide whether to finance the investments through internal financing, debt or equity. Therefore, the decision of the capital structure is very important for enhancing the financial performance of the firms (Bhattarai, 2016). In literature, it is identified that debt ratio (capital structure) and performance of the firm are negatively associated (Pouraghajan et al., 2012; Salteh et al., 2012). Some researchers have concluded that capital structure and firm's performance are directly associated (Kazempour \& Aghaei, 2015; Adesina, Nwidobie \& Adesina, 2015).In the developing countries where the stock exchange is barely functional and capital markets are inefficient, firms have only choice to finance its investments through debts. Therefore, financing decisions of the firm may face irregularity (Eldomiaty, 2007). First theory regarding capital structure was given by Modigliani \& Miller (1958, 1961) that is also known as irrelevance theorem. This theory proposes that under certain (unrealistic) assumptions like if there are no taxes and agency costs, there must be no bankruptcy and markets must operate perfectly, the capital structure is irrelevant, and it has nothing to do with the value/performance of firm. According to proposition of irrelevancy of the capital structure, there are three main assumptions. Market value of the firm is not related to and is not affected by the debt-equity ratio. But this is possible only under certain assumptions like capital market is perfect, capital structure irrelevancy with and without taxes. The authors basically studied two firms having different capital structures. One having debt while other without debt in its capital structure. They made a conclusion that market value of the firms is not affected by the financial decisions of the firms (assuming both firms having equal cash flows) (Brigham \& Ehrhardt, 2010).

\subsection{Corporate Governance Practices of Firm and Dividend Payout Policy}

Aligning the interests of managers and investors is known as corporate governance. With corporate governance, it is made sure that company exists for the benefits of investors and shareholders (Mayer, 2007). Corporate governance is a sort of promise that investor will get a return on the amount invested and that the firm will be operated with some specific rules and regulation in interest of the shareholders 
(Metrick \& Ishil, 2002). Corporate governance was needed because there was a clear conflict between the interests of managers and shareholders. Corporate governance is the basic answer for agency problems. There are different corporate governance practices even in the same country. Different firms can operate under different regulations (Ikunda et al., 2016). Managers usually retain the dividends so that risk of human capital loss can be mitigated. If the firm pays lower dividends, this implies that corporate governance is not up to the mark and hence the rights of shareholder's are not protected. The investors in the countries where rights are more protected and legal standards are high receive more dividends. However, in the countries where the legal protection is weak, dividend payout is low (La Porta et al., 2000). If the shareholder's rights are strong, then the severity of agency costs decreases (Gompers et al., 2003). In the companies where the rights of the shareholders are repressed are more likely to be exposed to agency problems. There is a wide gap between property and control in such companies. This is claimed that better the corporate governance practices are, higher the dividends paid by the company (Bebczuk, 2005). Quality of corporate governance can be tested with the help of Transparency Disclosure Index (TDI). Corporate governance code is the tool that helps in determining the dividend policy. Researchers found that the transparency disclosure index and dividend policy are correlated positively (Kowalewski et al., 2008). Agency problems become severe if the minority stockholder's rights are weak therefore, a separation is required between control and property of the firm. Managers usually prefer control and pays low dividends (Montalvan et al., 2017). Dividend policy and how it is affected by the corporate governance is what agency theory explains. The companies with stronger corporate governance are the ones that pays high dividends to its shareholders (Jang-chul \& Young, 2011). If the ownership structure is highly concentrated, then the dividend payout ratio may decrease because there is absence of supervision mechanisms.

\subsection{Board Size}

Number of directors in the board is known as board size and it is key determinant for the success and competence of the board (Ikunda et al., 2016). The bigger the board is, more effective is the company's management and reduced are the agency costs. If these agency costs rise, the poor management can lead to poor financial results and performance (Hamdouni, 2012). Board diversity increases as the size of board increases. Board diversity may include skills, gender diversity, nationality, experience and skills. Smaller boards do not have this diversity of experience and opinion (Dalton et al., 2009). But there are some costs related to the larger board sizes. There are costs related to coordination, planning, work coordination, decision-making and meeting costs. Holding meetings also become difficult when the board size is large. Corporate governance was a solution for agency problems but with the larger board sizes, the agency problems may increase. The role of board of directors can become more conflicting rather than functioning as a part of management. The possibility of free riding by the directors can be reduced if the board sizes are smaller. This also increases decision-making process (Raheja, 2005). If the board size is large, then usefulness of the board can be enhanced because a larger board size brings the expertise and skills that can be used for decreasing agency problems. According to some authors, the efficient board size of the firm is eight or above eight members. Small board sizes can cause the decision-making of directors to be inclined towards the decisions that are beneficial to them only rather than the firm. But if board size increases the difference in opinion can make the decision-making more efficient and beneficial to the shareholders (Byoun et al., 2016). The larger boards with more directors is preferred over the smaller boards with lesser directors because more directors will hold more experience, knowledge, skills and external links (Pahi \& Yadav, 2018). Small board size and dividend payout policy are directly related however some studies also claims an inverse relationship between two (Bolbol, 2012). If the company's board has sufficient number of members, then the operations can run smoothly, and business may not face challenges. Sufficient number of board members also makes sure that opportunistic behavior of the management is monitored. Larger boards can help to enhance the performance and they can help in mitigation of agency problems. Boards that are larger in size also help in smooth dividend payout ratios. However, there are some issues that a firm can face if board size is large. The lack of coordination and communication is the biggest issue that a large board can face. This problem leads to poor governance and poor dividend payout policy (Dissanayake \& Bandara, 2018). 
Researchers have suggested a direct association between the size of the board and the dividend payout policy (Kiel \& Nicholson, 2003).

\subsection{Corporate Governance Practices of Firm and Business Performance}

The new normal period of China is in which the returns on investment (ROI) are slack. Corporate governance is the key priority in this period. Corporate governance can result in better management and enhanced productivity of the firms. Chinese stock market's evaluation to study the relationship was done using data from 1999-2015. According to the study, board independence has no association with the performance of the firms. In 2002, specifically, the rule was passed that one out of three directors should be independent and profitability increased after implementation. Results also showed that if the gap between salaries of executives and staff is wide, productivity is damaged but ROA and ROE increases hence the performance gets better. Excessive concentration of ownership is also harmful but up to a certain limit, performance is increased (Molnar et al., 2017). To study the corporate governance essentials and financial performance of the firms, data was collected from securities and exchange board of India (SEBI). According to SEBI, the corporate governance practices must not be mentioned in books but should also be implemented and practiced. According to results, the Tobin Q ratio and the corporate governance scores were highly correlated. But the individual corporate governance parameters have no significant association with the profitability and performance (Goel \& Ramesh, 2016). Indian tourism sector was also studied to check the effect of corporate governance on the firm performance. 39 hotels that were listed on (Bombay Stock Exchange were the sample for the study. Time period of the study was 2013-2016 and ordinary least square and regression was used as data analysis technique. Results revealed that board's size and audit committee size are inversely related to hotel performance. Diligence and board's composition have a positive association with the performance of the hotels (Yameen et al., 2019).

\section{Theoretical Model of Study}

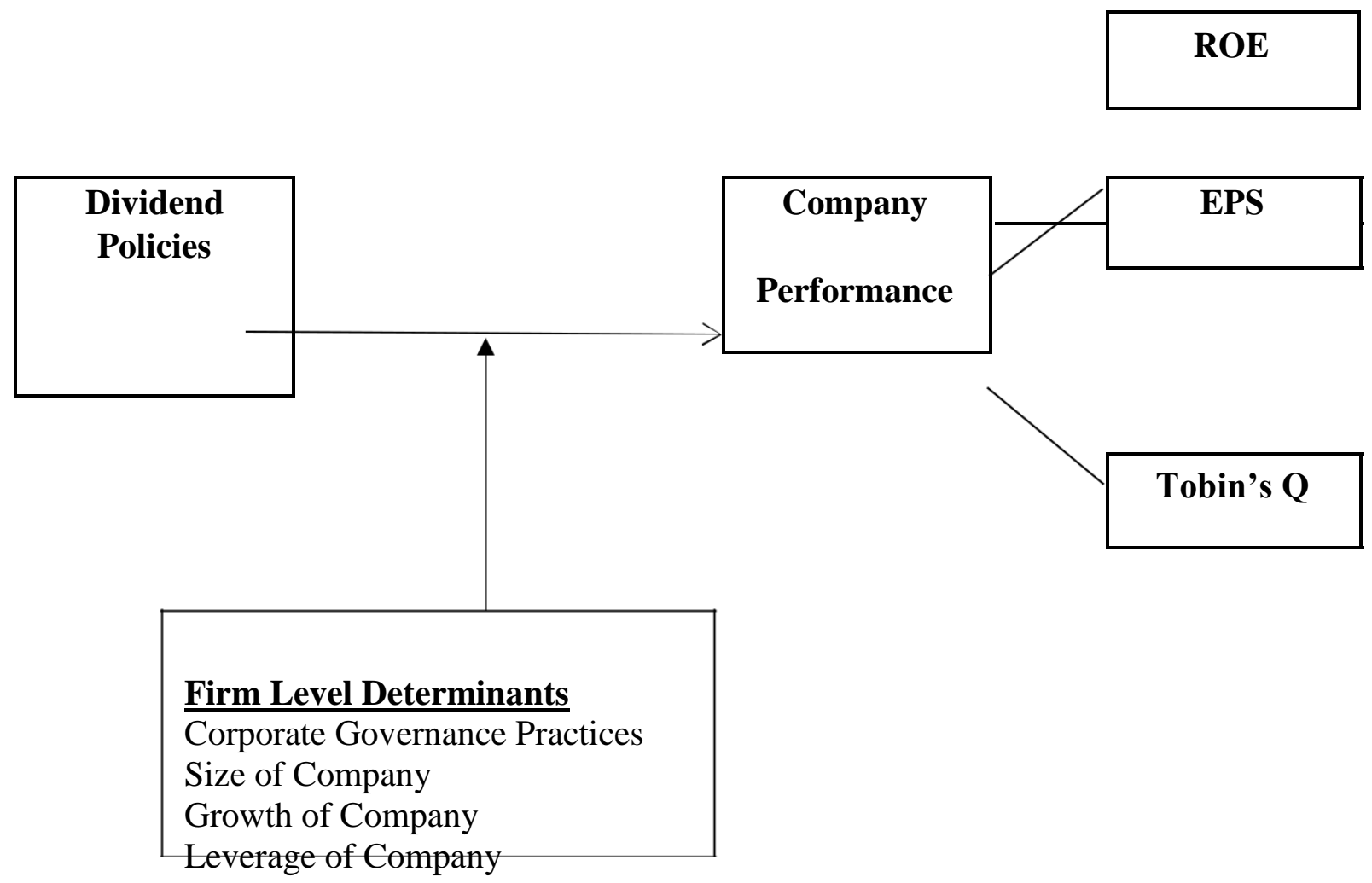

Theoretical Framework 


\section{Hypotheses of Study}

H1a: Dividend payout policy influences return on equity of automobile sector of Pakistan

H1b: Dividend payout policy influences earnings per share of automobile sector of Pakistan

H1c: Dividend payout policy influences Tobin's Q ratio of automobile sector of Pakistan

\section{Methodology}

This section consists of the details about the research design, methodology and approach that have been taken to conduct the current research. The study has employed panel data considering the number of companies that are taken understudy from each sector of research and the reading that is done for specific time period in each panel makes time line panel data. This part has been divided in segments in such a way that each segment is covering an aspect of methodology in detail such as population, data sources and variables of study and data analysis techniques. The sectors are already explained in detail in sampling framework, we have focused on the companies that are enlisted in stock exchange of the country and the ones that are being taken from each sector to conduct the research. Independent and dependent variables and the formulation of predictors that are functioning as controlling variables described in detail. Pooled OLS regression, fixed effect and random effect models are used as computation method to analyze the collected panel data. The details of data, data collection, population, variables and other measures are stated below.

\subsection{Population and Sample}

The sample taken to conduct the research in this study is five non-financial corporate sectors of Pakistan including cement. 100 companies from automobile sector, focused to collect the data from. This study has focused on the companies whose data were complete, those who were going through to pay dividend at least 4 years out of 6 years data collected. In total, the sample population of the current study includes 100 companies from automobile sector undertaken to conduct the research. This cumulatively forms the panel data of 100 companies with 600 numbers of total observations.

\subsection{Automobile Sector}

The automotive industry of Pakistan is a fastest growing industry contributing $4 \%$ in total GDP in Pakistan's economy and employing more than 1,800,000 people in the industry. 3,200 automotive plants are currently operating in the country, with investment of 92 billion PKR and producing 200000 vehicles and 1.8 million motorbikes in a year. The industry contributes around 50 billion PKR in Pakistan's national exchequer (Asghar, 2019). The possibility of expansion plans and increasing investment in the market of automobile sector in Pakistan is attracting local and foreign investors with the prospect of making potential profits in the sector. Many national and international automotive players are interested to invest in Pakistan's automobile sector considering the attractive incentives offered under auto policy of Pakistan (Ansari, 2018). Considering this scenario, Automobile is another massive and interesting sector to study that how the companies in Pakistan's automobile sectors are dealing with dividend payout policy to increase its financial performance and simultaneously to attract the shareholders and investors for more investments. The current study selects 16 companies from Automobile sector as a sample to conduct the research.

\subsection{Data Collection Sources}

The research is relying on the study the secondary data which is retrieved from authentic reports and financial statements of the selected companies. On the other hand, share price of selected companies are publically available at Pakistan Stock Exchange from where market capitalization data was collected. The data is retrieved for the time period of 6 years to construct the time series for each cross section. On the other hand, to develop the body of knowledge data was collected from reputed publications and comprehensive review of literature is conducted. 


\subsection{Period of Analysis}

Data from selected companies was collected for the period of 6 years (2012-2017). The research design involves a time series and cross sectional data therefore the study employs the method that is used to analyze a panel data. There are several advantages to use panel data for this kind of study including that panel data technique provides more freedom and variability which reduces the issues associated with collinear nature among independent variables; it also controls the individual heterogeneity (Antoniou et al., 2008). Moreover, panel data techniques have a better ability to determine the effects that are difficult in fact impossible to be detected in pure time series or cross sectional data (Baltagi, 2005).

\subsection{Formulation of Variables}

The study aims to evaluate the influence of dividend payout policy on the financial performance of the selected companies. However, the study has associated certain measures with independent and dependent variables along with inducing the controlling factors. These controlling variables are selected to determine that how these predictors influence the dividend payout policy of a company or how dividend payout policy behave in the presence of these predictors before influencing the financial performance of the respective firms. The measures for all the variables are stated below in detail.

\subsection{Dependent Variable}

The dependent variable of the study is financial performance of the firm as the influence of independent variable dividend payout policy is being checked on it in the research. The Financial performance of organizations is measured by the profit they make and this profitability is evaluated by calculating various profitability measures or profitability ratios such as return on equity, earning per share, and Tobin's Q. Financial and non-financial companies around the globe frequently utilize these measures to determine the financial performance of an organization (Khan and Ali, 2017). Following are the brief definitions of the ratios that are used as profitability measures to evaluate financial performance of the selected firms as these major profitability ratios are most suitable in context of the current subject.

- ROE: ROE or return on equity is calculated by dividing profit after tax with total equity. This ratio indicates that how much profit a company has generated against company's equity (Kabajeh et al., 2012).

- Tobin's Q: Tobin's Q ratio is equivalent to organization's market value divided by the cost of its assets' of automobile cost (Damodaran, 2002). Or

Tobin's $Q=A$ ratio comparing the market value of stock with equity book value of firm $\mathrm{i}$ in year $\mathrm{t}$ [(Equity market value + liability book value $) \div$ (equity book value + liability book value $)]$

- EPS: Earnings per share can be explained as "the portion of organizational profit that is allocated to each outstanding share of its common stock". It can be calculated by taking difference of organization's net income and the dividends that the organization pays for preferred stock. The difference is then divided by average number of outstanding shares. Earnings per share are usually reported by organizations on quarterly or annual basis (Islam et al., 2014).

\subsection{Independent Variable}

The independent variable of the study is dividend payout policy that a firm adopts as its influence is being checked on the financial performance of the respective firm taken in the study.

\subsection{Dividend Policy}

The policy that financial managers adopt in a firm to distribute their profit among shareholders as dividend or to hold their earning in the firm to use it in future investment for growth purposes is considered as dividend payout policy in the field of finance (Khan, et al., 2016). 
- Dividend payout ratio refers to the ratio of total paid out amount of dividends that are divided among shareholders in relation to net income of an organization (Odum, et al., 2019). It can be also explained as percentage of net earnings paid to the shareholders in form of dividends. The amount of earning that distributed as dividend to the shareholders is reserved by the organization from which it pays off debts or reinvests in core business operations. The dividend payout ratio indicates the amount of money that the organization is returning to shareholders against the amount that it is retaining to reinvest for the growth of organization, to pay off debt, or to add in cash reserves (Hamil and Al-Shattarat, 2012). However, how the behavior of this variable changes with governance practices and current status of the organization to enhance or destabilize its financial performance is yet to be further explored which this study aims to achieve.

\subsection{Control Variables}

The influence of independent variables is investigated according to their behavior with governance practices, size, growth and leverage of the organization which are controlling variables of the study.

- Size of the company for the current study is measured by using the natural log of company's total assets.

- Growth of the company for the current study is measured by using the natural log of company's total sales.

- Leverage is the equilibrium of Debt and Equity.

- Corporate Governance Index or Corporate Governance Practices Index is taken as follow: Sum of

$$
B D=\text { Number of directors on board, which used as natural log form }
$$

$I D=$ Proportion of independent directors (\# of independent director $\div$ \# of total directors on board)

$B M=$ Total number of meeting held by the broad, which used as natural log form

CEO Duality = value of "O" assignment if the CEO and chairman position is held by same person or otherwise " 1 ".

\subsection{Model Specification}

The model selection is done when the researcher needs to mathematically define relationship between dependent and independent variables. For a most suitable model selection, it is required to take Goldilocks balance approach by taking correct and suitable number of independent variables in regression equation. Too few variables make a model under specified and results into biased approach. Too many variables results into over specified models which are less precise. This is why appropriate number of variables should be taken to achieve a most precise model (Frost, 2019). The below model is specified for the current study for a more precise result.

\subsection{Statistical Analysis}

Statistical Models that are employed in the research are very instrumental to carry out the analysis. Descriptive analysis is required to check the behavior of the selected variables first which is done with Mean, Std. Deviation, Skewness and Kurtosis.

\subsection{Pooled Ordinary Least Squares (OLS)}

The current study employs Pooled Ordinary Least Squares (OLS) because it is a precise and accurate technique to estimate the dynamics of the model in panel assumptions (Hill et al., 2008). Pooled OLS tends to ignore panel structure of data and assumes that the companies taken for the analysis are 
homogenous, thus, the effect of cross sectional or time series is not significant (Shah, 2015). In nutshell, Pooled OLS assumes the coefficient and intercept as constant.

\subsection{Fixed Effect Model}

Fixed-effects (FE) method is used when the study is focusing on evaluating the influence of variables that are varying over time. In the current scenario the FE explores the relationship among predictors and outcome variables of financial variables within the selected companies with their individual characteristics that may have or not have an influence on the predicting variables. Using Fixed Effect will control the individual characteristics of the company that may influence the predictor and outcome. This possibility of influencing characteristic is also denoted as error term. With this rationale, fixed effect gives out the equation model (Stock and Watson, 2003).

$$
\text { Yit }=\beta 1 X i t+\alpha i+u i t
$$

\section{Where}

- Yit is the dependent variable where $i=$ company or any other entity and $t=$ time.

- Xit is one independent variable, $i=$ entity and $t=$ time

- $\beta 1$ is the coefficient for that Independent Variable

- $\alpha i(i=1 \ldots . . n)$ is the unknown intercept for each entity and $n$ entity-specific intercepts).

- uit is the error term

\subsection{Random Effect Model}

In Random effect (RE), the variation throughout the entities is assumed as random and not correlated with independent variables and predictors that are included in the model. In short, Random effect assumes that error term of the entity is not correlated with predictors which enable the time invariant variables to function as explanatory variables (Green, 2008). The equation of random effect is made as:

Yit $=\beta$ Xit $+\alpha+$ uit $+\varepsilon$ it

Where uit= between entity error and $\varepsilon i t=$ within entity error.

\subsection{Statistical Computation}

Tobin's Q(Automobile i) $=\alpha+\beta 1 \mathrm{DP}+\beta 2$ Size $+\beta 3$ Growth $+\beta 4$ Leverage $+\beta 5 \mathrm{CG}$ index + e Eq 2.1

EPS (Automobile i) $=\alpha+\beta 1 \mathrm{DP}+\beta 2$ Size $+\beta 3$ Growth $+\beta 4$ Leverage $+\beta 5 \mathrm{CG}$ index + e Eq 2

$\operatorname{ROE}($ Automobile $\mathrm{i})=\alpha+\beta 1 \mathrm{DP}+\beta 2 \mathrm{Size}+\beta 3$ Growth $+\beta 4$ Leverage $+\beta 5 \mathrm{CG}$ index + e Eq 2.3

\section{Data Analysis and Findings}

This part covers result of study along with interpretation. Firstly, descriptive statistics show the mean, std. deviation, skewness and kurtosis values for each sector separately. Secondly, unit root test is applied to find out whether data is stationary or not. Next, correlation statistics is applied to check whether there is multicollinearity issue in data or not then Lagrange multiplier is applied. After preestimation panel regression is used to predict the panel effect for each sector separately. Results of the study based on OLS regression, fixed effect and random effect and interpretation of for each sector is given separately.

\section{Descriptive Statistics Automobile Sector}




\section{Deviation}

\begin{tabular}{lllllll}
\hline Tobin's Q & 2.849 & 12.024 & 0.163 & 2.219 & 1.554 & 6.852 \\
EPS Rs. & 29.256 & 165.410 & -152.780 & 38.230 & 0.023 & 9.102 \\
ROE $(\% \Delta)$ & 0.215 & 1.100 & -1.936 & 0.302 & -3.429 & 8.740 \\
Dividend Payout & 0.331 & 2.150 & -0.458 & 0.343 & 2.893 & 6.098 \\
Size (Rs. 000) & 10292959 & 63879723 & 895117 & 13152237 & 2.333 & 8.230 \\
Leverage & 0.888 & 7.414 & 0.000 & 0.938 & 4.105 & 7.008 \\
Growth (Rs. 000) & 20354105 & 112000000 & 1111227 & 26792171 & 1.824 & 5.584 \\
Corporate Governance & 5.405 & 7.274 & 4.475 & 0.547 & -0.052 & 3.958 \\
\hline
\end{tabular}

(Self- Generated)

It has been evidenced from descriptive statistics that Tobin's Q has mean (2.849) and the same deviates to (0.163). Earnings per share on the other hand have mean Rs. 29.25 (EPS) and the same deviates to the 38.23. Here, skewness and kurtosis values are high (skewness $>1.0 \&$ kurtosis $>$ 3.0). Return on equity of automobile companies reported mean value $21.5 \%$ and the same deviates to the 30.2. Skewness and kurtosis values are quite high (skewness $=-3.429 \&$ kurtosis $=8.740$ ). To the dividend payout ratio automobile companies had 0.331 average payout which deviates to the value 0.343. Here, skewness and kurtosis values are high (skewness $>1.0 \&$ kurtosis $>3.0$ ). Size of automobile companies is range in between $R s .0 .89$ billion to Rs. 63 billion (quite dispersed) with average size value $=R s$. 10 billion. Here, skewness and kurtosis values are quite high (skewness $=2.33 \&$ kurtosis $=8.230$ ). In response to the growth (natural log of sales) of automobile companies, it is evident that maximum sales were found $R s .122$ billion and the minimum sales during the period were $R s .1 .1$ billion with average sales figure $=R s$. 20.3 billion. Here, skewness and kurtosis values are (skewness $=1.82 \&$ kurtosis $=5.584$ ). To the leverage of automobile companies, it is found that average debt to equity ratio $=0.888$ and it deviates to the value 0.938 . Here, skewness and kurtosis values are quite high (skewness $=4.105 \&$ kurtosis $=$ 7.008). Corporate governance index of automobile companies reported mean value 5.405 and the same deviates to the 0.547 .

\section{Unit Root Automobile Sector}

\begin{tabular}{llll}
\hline Variables & Method & Static at level & p -value \\
\hline Tobin's Q & Levin, Lin \& Chu t & -2.24985 & 0.0122 \\
Earnings per Share & Levin, Lin \& Chu t & -36.9782 & 0.0000 \\
Returns on Equity & Levin, Lin \& Chu t & -7.22772 & 0.0000 \\
Dividend Payout & Levin, Lin \& Chu t & -8.70388 & 0.0000 \\
Size & Levin, Lin \& Chu t & -18.6257 & 0.0000 \\
Growth & Levin, Lin \& Chu t & -13.0630 & 0.0000 \\
Leverage & Levin, Lin \& Chu t & -16.2804 & 0.0000 \\
Corporate Governance Index & Levin, Lin \& Chu t & -13.7443 & 0.0000 \\
\hline
\end{tabular}

(Self- Generated)

Results from above table to the unit root based on Levin et al. (2002) show that all variables have $t$ static values significant $(p$ value $<0.05)$ at level. With assumption of common autoregressive coefficients $(\beta)$ 
across the 16 cross-sections of automobile companies ( $\mathrm{pi}=\mathrm{p})$. It is found that $(\mathrm{H} 0: \alpha=0)$ does not support owing to the $\mathrm{t}$ static values are significant ( $\mathrm{p}$ value $<0.050$ ). Consequently, all variables including Tobin's $\mathrm{Q}$, earnings per share, equity returns, dividend payout ratio, size of automobile companies, debt to equity ratio/leverage, growth of automobile companies and corporate governance index do not contain unit root. It is, therefore, data series are stationary at level $((\mathrm{H} 1: \alpha<0)$.

\section{Correlation Automobile Sector}

\begin{tabular}{lllllllll}
\hline & Tobin's & & & & & & \\
& Q & EPS & ROE & DP & Size & Growth & Leverage & CG \\
\hline Tobin's Q & 1.000 & 0.390 & 0.395 & 0.260 & 0.205 & 0.311 & 0.239 & -0.089 \\
EPS & 0.390 & 1.000 & 0.579 & 0.352 & 0.576 & -0.048 & 0.618 & -0.091 \\
ROE & 0.395 & 0.579 & 1.000 & 0.447 & 0.241 & 0.076 & 0.306 & -0.122 \\
DP & 0.260 & 0.352 & 0.447 & 1.000 & 0.282 & 0.095 & 0.292 & -0.053 \\
Size & 0.205 & 0.576 & 0.241 & 0.282 & 1.000 & 0.262 & 0.994 & -0.002 \\
Growth & 0.311 & -0.048 & 0.076 & 0.095 & 0.262 & 1.000 & 0.272 & -0.166 \\
Leverage & 0.239 & 0.618 & 0.306 & 0.292 & 0.994 & 0.272 & 1.000 & -0.026 \\
CG & -0.089 & -0.091 & -0.122 & -0.053 & -0.002 & -0.166 & -0.026 & 1.000 \\
\hline
\end{tabular}

(Self- Generated)

Pearson's Correlation matrix depicts level of multicollinearity of Tobin's Q, earnings per share, equity return of automobile companies (16 cross sections) with dividend payout policy and other controlling factors. The highest level of multicollinearity of Tobin's $Q$ found with growth $(31.1 \%)$. On the other side the lowest level of multicollinearity of Tobin's Q of automobile companies was found with corporate governance index $(8.9 \%)$. However, these multicollinearity static values are not causing serious problem, if correlation coefficients are $=+/-0.80$. The highest level of multicollinearity of earnings per share is found with leverage $(61.8 \%)$. On the other side the lowest level of multicollinearity of earnings per share of automobile companies are found with growth (4.8\%). On the other hand the highest level of multicollinearity of equity returns of automobile companies are found with dividend payout (44.7\%) and the lowest level of multicollinearity of equity returns are found with growth $(7.6 \%)$. However, these multicollinearity static values are not causing serious problem of multicollinearity.

\section{Lagrange Multiplier (LM) \& Huasman Test}

\begin{tabular}{llll}
\hline & Chibar 2 (1) & P value & Proposed Test \\
\hline LM Test & 37.549 & 0.000 & OLS/Random Effect \\
Hausman Test & 2.000 & 0.849 & Random/ Fixed Effect \\
\hline
\end{tabular}

$\mathrm{LM}$ static value $=37.54(\mathrm{p}$ value $<0.05)$ therefore the variance across the 16 automobile companies is other than 0.00 and here the panel effect is assumed. Next, the Hausman test posits that unique error terms (ui) are not significantly correlated with regressor in automobile company's 
therefore, random effect is appropriate for the model.

\section{Regression Analysis: Tobin's Q Automobile Sector}

\begin{tabular}{|c|c|c|c|c|c|c|c|c|c|}
\hline \multirow[t]{2}{*}{ Models } & \multicolumn{2}{|c|}{ (OLS) } & \multirow[b]{2}{*}{$\mathbf{p}$} & \multicolumn{3}{|c|}{ Random Effect } & \multicolumn{3}{|c|}{ Fixed Effect } \\
\hline & $\boldsymbol{\beta}$ & $\mathbf{t}$ & & $\boldsymbol{\beta}$ & $\mathbf{t}$ & $\mathbf{p}$ & $\beta$ & $\mathbf{t}$ & $\mathbf{p}$ \\
\hline Dividend Payout & 1.19 & 1.90 & 0.06 & 0.29 & -2.46 & 0.01 & 0.71 & 1.29 & 0.20 \\
\hline Size & -1.41 & -2.78 & 0.01 & -1.53 & -3.21 & 0.00 & -1.76 & -2.79 & 0.01 \\
\hline Leverage & 0.58 & 2.52 & 0.01 & 0.36 & 1.68 & 0.10 & -0.26 & -0.97 & 0.33 \\
\hline Growth & 1.41 & 2.89 & 0.00 & 1.54 & 3.35 & 0.00 & 1.82 & 2.97 & 0.00 \\
\hline Corporate Governance & 0.08 & 0.22 & 0.83 & 0.09 & 0.25 & 0.81 & 0.11 & 0.20 & 0.84 \\
\hline Constant & 0.86 & 0.38 & 0.71 & 0.97 & 0.45 & 0.65 & 0.87 & 0.27 & 0.78 \\
\hline R Square & 0.227 & & & 0.342 & & & 0.566 & & \\
\hline Adjusted R Square & 0.184 & & & 0.287 & & & 0.450 & & \\
\hline F value & 5.305 & & 0.000 & 6.256 & & 0.000 & 04.892 & & 0.000 \\
\hline
\end{tabular}

(Self- Generated)

Based on random effect model adjusted R square predicts 34.2 percent variance in Tobin's Q owing the predictor dividend payout policy of automobile companies with controlling role of company

Size and leverage ratio. F statistic $=6.256 \& \mathrm{p}$ value $=0.000<0.05$ hence coefficients in the model are different than 0.00 . Coefficient of dividend payout ratio $(\chi 1)$ of automobile companies causes indirect 0.55 unit change in Tobin's Q (y) when dividend payout ratio increases by one unit. This relationship is controlled negatively with size of automobile companies, if size of company increases relationship is controlled negatively. Leverage on the other hand also controls the same relationship of negatively.

\section{Lagrange Multiplier (LM) \& Huasman Test}

\begin{tabular}{llll}
\hline & Chibar 2(1) & P value & Proposed Test \\
\hline LM Test & 31.325 & 0.000 & OLS/Random Effect \\
Hausman Test & 7.994 & 0.156 & Random/ Fixed Effect \\
\hline
\end{tabular}

LM static value $=31.32(\mathrm{p}$ value $<0.05)$ therefore the variance across the 16 automobile companies is other than 0.00 and here the panel effect is assumed. Next, the Hausman test posits that unique error terms (ui) are not significantly correlated with regress or in automobile company's therefore random effect is appropriate for the model.

\section{Regression Analysis: EPS Automobile Sector}

\begin{tabular}{|c|c|c|c|c|c|c|c|c|c|}
\hline \multirow[t]{2}{*}{ Models } & \multicolumn{2}{|c|}{ (OLS) } & & \multicolumn{3}{|c|}{ Random Effect } & \multicolumn{3}{|c|}{ Fixed Effect } \\
\hline & $\beta$ & $\mathbf{t}$ & $\mathbf{p}$ & $\beta$ & $\mathbf{t}$ & $\mathbf{p}$ & $\beta$ & $\mathbf{t}$ & $\mathbf{p}$ \\
\hline
\end{tabular}




\begin{tabular}{|c|c|c|c|c|c|c|c|c|c|}
\hline Dividend Payout & -0.71 & -2.31 & 0.02 & -0.75 & -2.77 & 0.01 & -0.82 & -2.82 & 0.01 \\
\hline Size & -1.16 & -4.65 & 0.00 & -1.17 & -4.55 & 0.00 & -1.13 & -3.86 & 0.00 \\
\hline Leverage & -0.42 & -3.71 & 0.00 & -0.40 & -3.56 & 0.00 & -0.39 & -3.10 & 0.00 \\
\hline Growth & 1.35 & 5.63 & 0.00 & 1.32 & 5.33 & 0.00 & 1.27 & 4.48 & 0.00 \\
\hline Corporate Governance & -0.11 & -0.56 & 0.58 & 0.07 & 0.32 & 0.75 & 0.23 & 0.88 & 0.38 \\
\hline Constant & -0.01 & -0.01 & 0.99 & -0.46 & -0.38 & 0.71 & -1.17 & -0.80 & 0.43 \\
\hline R Square & 0.577 & & & 0.557 & & & 0.786 & & \\
\hline Adjusted R Square & 0.554 & & & 0.533 & & & 0.729 & & \\
\hline F value & 24.653 & & 0.000 & 22.716 & & 0.000 & 13.779 & & 0.000 \\
\hline
\end{tabular}

(Self- Generated)

Based on random effect model adjusted $\mathrm{R}$ square predicts 53.3 percent variance in earnings per share owing the predictor dividend payout policy of automobile companies with controlling role of company size \& growth and leverage ratio. F statistic $=22.71 \& \mathrm{p}$ value $=0.000<0.05$ hence coefficients in the model are different than 0.00 . Coefficient of dividend payout ratio $(\chi 1)$ of automobile companies causes indirect 0.75 unit change in earnings per share $(\mathrm{y})$ when dividend payout ratio increases by one unit. This relationship is controlled negatively with leverage and size of automobile companies, if creditors' stake increases relationship is controlled negatively and if size increases the relationship is controlled negatively. Growth on the other hand controls the same relationship of positively.

Lagrange Multiplier (LM) \& Huasman Test

\begin{tabular}{llll}
\hline & Chibar 2 (1) & P value & Proposed Test \\
\hline LM Test & 4.190 & 0.040 & OLS/Random Effect \\
Hausman Test & 9.321 & 0.080 & Random/ Fixed Effect \\
\hline
\end{tabular}

LM static value $=4.190(\mathrm{p}$ value $<0.05)$ therefore the variance across the 16 automobile companies is other than 0.00 and here the panel effect is assumed. Next, the Hausman test posits that unique error terms (ui) are not significantly correlated with regressor in automobile companies, therefore random effect is appropriate for the model.

\section{Regression Analysis: ROE Automobile Sector}

\begin{tabular}{lccccccccc}
\hline Models & \multicolumn{2}{c}{ (OLS) } & \multicolumn{3}{c}{ Random Effect } & \multicolumn{3}{c}{ Fixed Effect } \\
& $\boldsymbol{\beta}$ & $\mathbf{t}$ & $\mathbf{p}$ & $\boldsymbol{\beta}$ & $\mathbf{t}$ & $\mathbf{p}$ & $\boldsymbol{\beta}$ & $\mathbf{t}$ & $\mathbf{p}$ \\
\hline Dividend Payout & 0.31 & 4.56 & 0.00 & 0.31 & 4.89 & 0.00 & 0.30 & 4.09 & 0.00 \\
Size & -0.39 & -7.09 & 0.00 & -0.44 & -7.94 & 0.00 & -0.60 & -8.15 & 0.00 \\
Leverage & -0.02 & -0.68 & 0.50 & -0.03 & -1.08 & 0.28 & -0.05 & -1.52 & 0.13
\end{tabular}




\begin{tabular}{lccccccccc} 
Growth & 0.39 & 7.34 & 0.00 & 0.44 & 8.17 & 0.00 & 0.60 & 8.36 & 0.00 \\
Corporate Governance & 0.00 & 0.10 & 0.92 & 0.01 & 0.19 & 0.85 & 0.01 & 0.20 & 0.84 \\
Constant & -0.04 & -0.16 & 0.88 & 0.31 & 4.89 & 0.00 & -0.12 & -0.32 & 0.75 \\
\hline R Square & 0.514 & & & 0.537 & & & 0.680 & & \\
Adjusted R Square & 0.487 & & & 0.511 & & & 0.595 & & \\
F value & 19.085 & 0.000 & 20.884 & & 0.00 & 7.998 & & 0.000
\end{tabular}

(Self-Generated)

Based on random effect model adjusted $\mathrm{R}$ square predicts 51.1 percent variance in return on equity owing the predictor dividend payout policy of automobile companies with controlling role of company growth and size. $\mathrm{F}$ statistic $=20.884 \& \mathrm{p}$ value $=0.000<0.05$ hence coefficients in the model are different than 0.00 . Coefficient of dividend payout ratio $(\chi 1)$ of automobile companies causes indirect 0.31 unit change in return on equity (y) when dividend payout ratio increases by one unit. This relationship is controlled negatively with size of automobile companies. Growth on the other hand controls the same relationship of positively.

\section{Discussion}

\subsection{Relationship of Dividend Payout Policy and Business Performance Automobile Sector}

The above results regarding the automobile sector, overall, support the dividend relevance theory proposed by Gordon (1959) that the profitability of a firm is affected by its dividend policy. Research study conducted by Lintner (1956) depicted that current years earning per share influence the dividends payment. It is asserted that change in dividend payout policy affects the future profitability of a firm. Therefore, results of the study revealed by Arnott \& Asness (2003) illustrated that the high level of current dividend payout is associated with firm profitability. Amidu \& Abor (2006) concluded that the relationship between dividend payout and firm's profitability support the dividend relevance theory. The study carried out by Thafani \& Abdullah (2014) revealed that there exists a significant positive association between dividend payout and profitability. This result also supports the dividend signaling effect, since it is argued that dividend may have a signaling effect. Information regarding the strategies of firm is maintained with the top management and they can also forecast company's future earnings. Thus, more information related to the firm is retained by managers comparatively to market's investors (Deeptee \& Roshan, 2009). It leads to the information asymmetry problem, therefore dividend signaling mechanism is used by firms which sends information to investors in the market. The information signaled reflects the strategies of firm which is intended to employ in long or short-run. Expectations of investors can be changed by the managers with regards to firm's future earnings through dividends (Deeptee \& Roshan, 2009). The agency theory of dividend payout policy is also addressed in the current research study, which deals with problems between managers and shareholders.

Agency theory was developed by Jensen and Meckling (1976) which states that agency costs are the sum of expenditures related to monitoring by the shareholders, the expenditures related to boning between managers and shareholders by the managers, and residual loss. It is evidenced that dividends payout are considered as one of the important aspect in reducing the agency conflicts. For instance, mangers for their own interests use resources of the firm rather than in the interests of shareholders. However, managers' deals with wasted part of resources and remaining costs are provided to shareholders who help in solving agency problems, thus benefiting shareholders' value (Caelers, 2010). Lastly, the study also support the bird in hand theory, as it is explained that bird in hand will have effect if dividends are used by investors for consumption or to purchase treasury bills, however if the received dividends by reinvesting in either the same or different firm, then their cash (less taxes paid) is 
committed to the similar risks as if no dividends exists, then the bird in hand will have no influence except any changes in the firm's investment policy. But if dividends are not received by the investors at their will at first, then it does not mean that investors have no desire for dividends since many investors are willing to wait for future dividends (Easterbrook 1984). Furthermore results of the study overall shows that company's growth has significant positive influence on profitability and it is in line with the findings of Razaq \& Akinlo (2017). Whereas, the study conducted by Aduralere Opeyemi (2019) revealed that firm size and profitability are significantly related, on the other hand results concluded by Azhar \& Ahmed (2019) are contradictory to current findings and stated that firm size has no significant influence on profitability.

\subsection{Key Findings}

The current study explores the relationship of dividend payout policy on the profitability of firms that exist in the non-financial corporate sector of Pakistan. 100 companies are selected from automobile sector. Relationship of dividend payout policy and business performance was controlled with four variables based on relevant theories. These variables include size of company, growth of company, leverage (debt to equity ratio) and corporate governance index. Panel data is collected from 2012-2017 (six years) and then analyzed. Following key findings for each research objective were obtained by applying the adopted research method on the data through the adopted method of analyses. The results generated regarding the dividend payout policy and profitability in the cement sector is as same as that of textile sector. Only there is one more controlling factor that is affecting the correlation of both the dependent and independent variables. In case of Pakistan's cement sector, besides size and leverage, firms' growth is also coming out as effective variable on the relationship which aligns with the signaling theory. Dividend signaling theory indicates that through dividend policy, firms send out the signals informing the prospective investors regarding the future prospect of the company. In this light it is observed that the growth of the firms that is measured by the total sales portfolio of the company effects the correlation of dividend and profitability if the sales portfolio of the company increases then investors catch the perception that the company has better chance of growth in the future and thus they realize that the less dividend pay-out of present can benefit them in future due to more profitability of the company. The result of the current study shows that a positive association exists between dividend payout policy and profitability of firms in automobile sector of Pakistan. The result aligns with the agency cost theory which means that the payment that firms make in form of dividends can be useful tool for financial managers of firms to control agency behavior. It can be said specifically that through induction of external funding, dividends can reduce agency costs and increase profitability of the firm. The positive association of dividend payout policy and firm's profitability can be seen in light if signaling theory as well because the dividend payout policy which makes handsome pay-out ratio to firms investors send out the impression that firm is making profit and therefore can engage more funds from the investors which will subsequently can be invested for firms growth and development which will eventually leads to the profitability of the firm. The positive outcome of the correlation of dependent and independent variables mitigates with bird in hand theory which states that shareholders who are averse to risks prefer dividend payments over prospect of future benefits by the firms' growth in capital. This is because dividends are returns at a regular specified time while future growth of firm in terms of capital is not certain for such investors. That is why the theory is phrased as 'bird-in-hand' theory. As per the developer of this theory Gordon and Miller, (1963) dividends reduce the uncertainty that makes the investors discount the future earnings of the company and thus increased the value and subsequently profitability of the firm (Gordon and Linter, 1963). The controlling variables of the study size, growth and leverage of the company effects the relationship of the dividend payout policy and profitability of automobile firms of Pakistan.

\section{Summary of Results}

\begin{tabular}{|l|c|c|c|}
\hline Sector & $\begin{array}{c}\text { Relationship of Dividend Payout and } \\
\text { Business Performance }\end{array}$ & $\begin{array}{c}\text { Theory } \\
\text { Support }\end{array}$ & Hypothesis \\
\hline
\end{tabular}




\begin{tabular}{|l|l|l|c|}
\hline Cement & Negative & Pecking Order Theory & Supported \\
\hline Automobile & Positive & $\begin{array}{l}\text { Agency Cost Theory/ Bird in Hand } \\
\text { Theory/Signaling Theory }\end{array}$ & Supported \\
\hline Automobile & Size, Leverage \& Growth & $\begin{array}{l}\text { Pecking Order Theory, } \\
\text { Agency Cost Theory \& } \\
\text { Signaling Theory }\end{array}$ & Supported \\
\hline
\end{tabular}

\section{Conclusion}

The current study investigates the influence of dividend payout policy on the profitability of companies by taking leading manufacturing industries of Pakistan under study. Companies from automobile sector, chosen for the purpose. The ratios of ROA (asset returns) and EPS (earning per share) are used to measure the profitability of the chosen companies. The study also includes controlling variables that might have controlling effect on the relationship of dividend payout policy and profitability of the firm. These variables are leverage of the company measured by the ratio of equity and debt, size of the company is measured by the total assets, growth of the company is measured by total revenue/sales and corporate governance index. After the analysis, the results of the study show that in 100 automobile companies, a negative relationship occurs between dividend payout policy and their profitability. Furthermore, size of the firm according to the pecking order theory (Myer, 1984) and leverage as per the agency cost theory (Meckling and Jensen, 1976) came out to have a significant controlling effect on this negative relationship. In the case of automobile industry, another controlling factor that is growth of the company was found to have an effect on the relationship between dividend payout policy and profitability in light of Signaling theory (Miller and Modigiliani, 1961). The automobile companies showed positive relationship between their dividend payout policy and profitability and it was concluded that both dependent and independent variables are positively related in this sector and size, growth and leverage are the controlling predictors of the relationship.

\section{Recommendations}

The results of current investigation make several implications and contribution to streamline the business practice regarding dividend payout policy in the non-financial companies from leading manufacturing industries of Pakistan. The positive influence of pay out based dividend payout policy on profitability of firms recommends the financial managers to build commitment with such policy and put consideration to stabilize their policy for dividend payments. The discussion and the results implicate that dividend payout policy in corporate sectors brings out information regarding the profit related prospects of the organization along with the estimation of growth that the firm may gain in future. This kind of information may engage the interest of potential investors which will in turn influence firm's value. The study further indicates that both existing and potential investors when invest in a firm particularly that are committed in dividends consider proper information relevant to the profitability, size, growth and investment opportunities because these elements determine that whether the firm profitability and value will elevate in the future. It is recommended that an appropriate dividend payout policy should be designed and implemented so the financial managers are not left to make decision that how the dividends should be paid but they are guided by a properly designed policy. The results also recommend a constant percentage of profit in a dividend payout policy as it brings certainty for the shareholders. As the share market positively response to dividend, firms should make effort to consistently pay dividend so their shares can well perform in market. As for the shareholders and investors, it is reasonable for them to government good earning on the investment they make but they should also realize that the reason behind unfavorable dividend pay-out ratio cannot always be bad profit but it can also be the firm's investment in growth which eventually be beneficial for the shareholders in form of a better dividend pay-out in future. As dividend payout policy affect firms' performance, therefore, companies must pay the dividend so that they gain a positive outlook in future. This scenario coincides with is bird-in-hand theory (Gordon and Linter, 1963), tax differential theory Litzenberger and Ramaswamy (1979), information signaling effect theory (MM, 1961) and agency theory (Meckling and Jensen, 1976). These popular theories states that dividend payout policy is significantly related to firm's performance when other factor of dividend payout policy is constant. 


\section{Future Directions}

The study makes a path that can lead future research and studies towards more conclusive and contributing results. It would most probably interest the academic scholars and other stakeholders if research in future will investigate that how profitability and dividend payout policy may be affected by tax policy, legal rules, opportunities and pattern of past payout of dividends. Other controlling predictors including ownership structure, expectations and tax position of shareholders, access to share market and industry practice should be considered as well in the future studies to determine if they can be of importance in designing a dividend policy. Moreover, results that showed insignificant values can be reconsidered in future by academicians as inconsistent results are noticed among the researches in past as well. The study moreover suggests that studies should be conducted to cover all types of financial and nonfinancial cooperative societies where researcher can make a comparison among the regression outcomes obtained to evaluate the variances in different types of financial and nonfinancial cooperative societies. Some more relationship that can shed more light on the proper dividend policies for different firms are relationship of dividend payout policy and managements' perception with financial performance of the firms and influence of external sources of funds on the dividend payout policy and profitability of companies. Furthermore, companies with various kinds of ownership and different structure such as private and public might use different means to communicate the future prospects of their earning to the shareholders. A study might come out to be useful if carried out on firms with highly dispersed and concentrated ownership to explore their dividend payout policy and its influence on their profitability.

\section{Limitations}

However, the study contributes immensely in the field of dividend payout policy and field of finance as a useful literature but like all other studies, it too has some limitations that can be covered in future. The study is entirely based on manufacturing companies or nonfinancial corporate sector of Pakistan which is a developing country. Therefore, the results reveal various financial aspects of manufacturing sector and that also in a developing country. The study cannot be deemed as conclusive for financial sectors as their dividend payout policy has totally different perspective and thus entirely a different influence on profitability. Moreover, there are very different predictors that may have a controlling effect on the relationship of dividend payout policy and their profitability (Yiadom and Agyei, 2011). Same is the case with the dividend payout policy and its influence on the profitability of firms that are located in developed countries (Aivazian, Booth \& Cleary, 2003). This is the reason that while the current study is conclusive and all-encompassing in nature in context of manufacturing sector in developing country but it doesn't cover the financial sectors or the prospect of developed countries. Furthermore, in current study, the data represents the time period of 6 years (2012 till 2017) which is taken understudy for the current research but it can be considered as the limitation of the study because the time period is short when compared to others taken in the popular literatures. Academicians can increase the time horizon in order to overcome this particular limitation in future.

\section{References}

Adediran, S. A., \& Alade, S. O. (2013). Dividend Policy and Corporate Performance in Nigeria, American Journal of Social and Management Sciences, 4 (2), 71-77

Ahmed, M., \& Rezaei-Gomari, S. (2019). Economic Feasibility Analysis of Shale Gas Extraction from UK's Carboniferous Bowland-Hodder Shale Unit. Resources, 8(1), 5.

Aivazian, V., Booth, L., \& Cleary, S. (2003). Do emerging market firms follow different dividend policies from US firms?. Journal of Financial research, 26(3), 371-387.

Amidu, M., \& Abor, J. (2006). Determinants of dividend payout ratios in Ghana. The journal of risk finance.

Amina, H. (2015). Dividend Policy and Corporate Governance in Saudi Stock Market: Outcome Model or Substitute Model? Corporate Ownership \& Control, 12(2).

Arnott, R. D., \& Asness, C. S. (2003). Surprise! Higher dividends= higher earnings growth. Financial 
Analysts Journal, 59(1), 70-87.

ASADI, A., \& ASGHARI, S. M. (2017). Surveying of capital structure effect and its change on profit division policy in companies accepted in Tehran Stock Exchange (TSE).

Baker, H. K., \& Powell, G. E. (1999). How corporate managers view dividend policy? Quarterly Journal of Business and Economics, 38(2), 17-35.

Black, F. (1976). The Dividend Puzzle. Journal of Portfolio Management, 2(2), 5-8.

Borad, S. B. (2019). Dividends - Forms, Advantages and Disadvantages, e-finance management.

Bragg, S. (2018). Types of dividends. Accounting tools. Retrieved from https://www.accountingtools.com/articles/2017/5/16/types-of-dividends

Business Jargons Finance (2017). Dividend Policy. http://businessjargons.com/dividend- Policy.html. Retrieved: May 23, 2017.

Caelers, L. (2010). The relation between dividend policies and agency conflicts. Tilburg University Thesis.

Chauhan, J., Ansari, M. S. Taqi, M., \& Ajmal, M. (2019). Dividend Policy and Its Impact on Performance of Indian Information Technology Companies. International Journal of Finance and Accounting, 8(1), 36-42.

Deeptee, P. R., \& Roshan, B. (2009). Signalling power of dividend on firms' future profits a literature review. International Interdisciplinary Journal, 1(1), 1-9.

Fama, E. F., \& Babiak, H. (1968). Dividend policy: An empirical analysis. Journal of the American Statistical Association, 63, 1132-1161.

Gordon, M. J. (1959). Dividends, earnings, and stock prices. The review of economics and statistics, 99105.

Hamdouni, A. (2012). Dividend Policy and Corporate Governance in Saudi Stock Market. Archives Des Sciences Journal, 65, 24-26.

Hamil, P. A., \& Al-Shattarat, W. (2012) What Determines the Dividend Payout Ratio for Jordanian Industrial Firms?, Journal of Emerging Market Finance, 11 (2), 161-187.

Hasan, M. (2015). Dividend Payout Ratio and Firm's Profitability. Evidence from Pakistan. Theoretical Economics Letters, 5, 441-44.

Hashemijoo, M., Mahdavi Ardekani, A., \& Younesi, N. (2012). The impact of dividend policy on share price volatility in the Malaysian stock market. Journal of business studies quarterly, 4(1).

Houmani Farahani, M., \& Ghara Jhafari, M. (2014). Impact of financial leverage on dividend policy at Tehran Stock Exchange: A case study in food industry. European Online Journal of Natural and Social Sciences: Proceedings, 2(3), pp-2788.

Idewele, I. O. E., \& Murad, B. A. (2019). Dividend policy and financial performance: a study of selected deposit money banks in Nigeria. African Journal of Business Management, 13(7), 239-255.

Islam, K., Bilal, A. R., Rehman, C. A., \& Ilyas, M. (2017). Literature Review on Dynamics and Determinants of Dividend Policy in Pakistan Evidences from Pakistan. Review of Public Administration and Management, 5, 218.

Jaffe, F. F., Westerfield, R. W., and Ross, S. A. (2002) Administração financeira, Corporate Finance, 2. Javed, O. (2019) Automobile Sector of Pakistan, Global Village Space, 17 January 2019.

Jensen, M. C., \& Meckling, W. H. (1976). Theory of the firm: Managerial behavior, agency costs and ownership structure. Journal of financial economics, 3(4), 305-360.

Kabajeh, M. A. M.,et al. (2012) The relationship between the ROA, ROE and ROI ratios with Jordanian insurance public companies market share prices, International Journal of Humanities and Social Science, 2(11), 115-120.

Khan, M. N. et al., (2016) Impact of Dividend Policy on Firm Performance: An Empirical Evidence from Pakistan Stock Exchange, American Journal of Economics, Finance and Management, 2 (4), 28-34

Kuzucu, N. (2015). Determinants of Dividend Policy: A Panel Data Analysis for Turkish Listed Firms. International Journal of Business and Management, 10(11).

Lai, T. K., Shan, L. H., \& Mun, H. W. (2016). The Impact of Dividend Policy on Firm performance in Consumer Product and Trading/Services Sector in Malaysia. International Journal for Research in 
Business, Management and Accounting, 90(2).

Lintner, J. (1956). Distribution of Incomes of Corporations among Dividends, Retained Earnings, and Taxes. American Economic Review, 46 (2), 97-113.

Lintner, J. (1962). Dividends, Earnings, Leverage, Stock Prices and Supply of Capital to Corporations. The Review of Economics and Statistics, 64, 243-269.

Maheshwari, S. N. (1999). Elements of Financial Management, Sultan Chand and Sons, p. 71.

Manos, R. (2002). Dividend policy and agency theory: evidence on Indian firms. Manchester: Institute for Development Policy and Management, University of Manchester.

Marfo-Yiadom, E., \& Agyei, S. K. (2011). Determinants of dividend policy of banks in Ghana. International Research Journal of Finance and Economics, 61(61), 99-108.

Mayer, F. (2007). Corporate Governance, Competition and Performance, Enterprise and Community.

Meckling, W. H. and Jensen, M. C. (1976) Theory of the Firm: Managerial Behavior, Agency Costs and Ownership Structure.

Miller, M. H., \& Modigliani, F. (1961) Dividend Policy and the Valuation of Shares, Journal of Business, October, 1961.

Myers, S. C. (1984). The capital structure Puzzle. Journal of Finance, 39(3), 575-592.

Myers, S. C., Majluf, N.S. (1984). Corporate financing and investment decisions when firms have information that investors do not have. Journal of Financial Economics, 13(2), 187-221.

Myers, S. C., Majluf, N.S. (1984). Corporate financing and investment decisions when firms have information that investors do not have. Journal of Financial Economics, 13(2), 187-221.

Ofori-Sasu, D., Abor, J. Y., \& Osei, A. K. (2017). Dividend Policy and Shareholders' Value: Evidence from Listed Companies in Ghana. African Development Review, 29(2), 293-304.

Omodero, C. O., \& Amah, K. O. (2017). Analysis of Dividend Policy and Its Impact on Shareholders Wealth Maximization in Nigerian Firms (A Study of Brewery Industry). Applied Economics and Finance, 4(5).

Opeyemi, A. (2019). The impact of Firm Size on Firms Performance in Nigeria: A comparative study of selected firms in the Building Industry in Nigeria. Asian Development Policy Review, 7(1), 1-11.

Panigrahi, S., \& Zainuddin, Y. (2015). Dividend policy decisions: Theoretical views and relevant issues. Reports on Economics and Finance, 1(1), 43-58.

Pruitt, S. W., \& Gitman, L. J. (1991). The interactions between the investments, financing and dividend decisions of major US firms. Financial Review, 26(3), 409-430.

Rahman, A. (2018). Effect of Dividend Policy on Firm's Performance: A Case Study of Automobile Sector of Pakistan. SEISENSE Journal of Management, 1(5), 6-15.

Ramcharran, H. (2001) Inter-firm linkages and profitability in the automobile industry: The implications for supply chain management, Journal of Supply Chain Management, 37(4), 11-17.

Razaq, I. T., \& Akinlo, A. E. (2017). Interrelationship between Size, growth and Profitability of NonFinancial Firms in Nigeria. European Journal of Business and Management, 9(7), 76-86.

Rehman, O. U. (2016). Impact of Capital Structure and Dividend Policy on Firm Value. Journal of Poverty, Investment and Development, 21(1).

Retrieved from https://efinancemanagement.com/dividend-decisions/dividends-forms-advantagesand-disadvantages

Rustagi, R. P. (2001). Financial Management, Galgotia Publishing Company, 806.

Shah, A. S. (2015). Dividend policy-A theory.

Thafani, A. R., \& Abdullah, M. (2014). Impact of dividend payout on corporate profitability: evident from Colombo stock exchange. Advances in Economics and Business management, 1(1), 27-33.

Toby, A. J. (2014). Empirical Test of the Dividend Policy Irrelevance Hypothesis in the Nigerian Context. Research Journal of Finance and Accounting, 5(6).

Uyar, A., Kuzey, C. (2014). Determinants of corporate cash holdings: Evidence from the emerging market of Turkey. Applied Economics, 46(9), 1035-1048.

Velnampy, T., Nimalthasan, P., \& Kalaiarasi, K. (2014). Dividend Policy and Firm Performance: Evidence from the Manufacturing Companies Listed on the Colombo Stock Exchange. Global Journal of Management and Business Research: Administration and Management, 14(6). 
Wasiuzzaman, S. (2014). Analysis of corporate cash holdings of firms in Malaysia. Journal of Asia Business Studies, 8(2), 118-135.

Yegon, C., Cheruiyot, J., \& Sang, J. (2014). Effects of dividend policy on firm's financial performance: Econometric analysis of listed manufacturing firms in Kenya. Research Journal of Finance and Accounting, 5(12), 136-144.

Younis, D., \& Javid, A. Y. (2014) Market Imperfections and Dividend Policy Decisions of Manufacturing Sector of Pakistan, Pakistan Institute of Development Economics, Paper 99-2014. 